\title{
Case detection; are the present survey methods effective? A review of leprosy surveys in Bombay
}

\author{
W S BHATKI \\ Acworth Leprosy Hospital, Bombay, India \\ Accepted for publication 26 January 1988
}

Summary The results of active surveys carried out in Bombay during the last 15 years show that such surveys predominantly detect non-infectious cases with 1-2 skin lesions. Considering the work input in terms of field workers' days required to detect each case, particularly an infectious case, the present survey methods are not cost effective. Health education is found to be more effective and efficient in case detection than active surveys.

Modified methods which can identify infectious cases at an early stage are discussed and suggested.

\section{Introduction}

SUR VEY

An important component of leprosy control programme, carries special value in the hyperendemic areas and aims at the following objectives: 1 , early diagnosis and treatment to cure the cases without residual damage, and 2, identification and treatment of infectious cases to break the chain of transmission.

Active case detection in the form of school surveys has been extensively carried out in Bombay since $1970 .{ }^{1}$ Surveys are also being routinely conducted in the city in other groups of the population such as household contacts, industrial workers, slum dwellers and the other residents of the city. Since the present survey methods are being adopted by the voluntary and government organizations as part of their routine work, the time has come to evaluate the methods and the results of the extensive survey work already carried out, in terms of their ability to fulfil the above said objectives.

\section{Case detection by survey methods}

The results of active surveys are summarized in Table 1 .

School surveys. Of all the surveys, school surveys have been the most extensively carried out as they experience least difficulties and the coverage of examination often exceeds $95 \%$. The case detection rates in school surveys ranged from 3 to $10 \cdot 8$ per 1000 . Over $90 \%$ of cases detected in school children had early leprosy, of which $80 \%$ had single skin lesions. ${ }^{1,2,3,5}$ Only $2-4 \%$ cases had smear + ve leprosy. This indicates that prevalence of inf ectious leprosy among children is low. This 
view is further supported by the results of the survey of non-school going children ${ }^{4}$ and that of the children of pre-school age.?

The finding that $60 \%$ of the lesions were found on the covered parts of the body, i.e. trunk and limbs up to knees and elbows, suggested that complete stripping of the body while carrying out surveys was necessary. ${ }^{2,5}$

Contact surveys. Though contacts of known leprosy patients are examined regularly at clinics, the contact surveys as such were undertaken later to find out the associated cases and the source of infection. Contact surveys showed high case detection rates, i.e. 30-60/1000 (Table 1). However it was interesting to note that the associated cases were predominantly non-infectious and they were found in the families of only $23 \%$ and $14 \%$ of cases, ${ }^{4,6}$ thus suggesting a possibility of an extrafamilial source of infection.

The results of school surveys suggested existence of hyperendemic pockets in different parts of Bombay, which in turn makes it necessary to examine the whole population.

Slum surveys. About $43 \%$ of the population of Bombay live in slums. ${ }^{5}$ Whole population surveys in slums are comparatively easy, generally giving $75-80 \%$ coverage. ${ }^{4,8}$ Case detection rates in different slums varied from 6 to 23 per 1000 with $9-10 \%$ infectious cases..$^{4,5,8}$ It was interesting to note that of the infectious cases, $94 \%$ were adults and $82 \%$ were male adults while the same population group, i.e. male adults, had the lowest coverage of examination, i.e. $60 \%{ }^{4}$

Survey of industrial workers. This survey was mainly undertaken to cover male adults who escape examination in door-to-door surveys. It has been observed that of the total adult cases registered at the Acworth Leprosy Hospital during the last 10 years, 33\% were industrial workers, of which $25-30 \%$ had smear + ve leprosy. ${ }^{9}$.

Table 1. Results of surveys carried out in Bombay

\begin{tabular}{|c|c|c|c|c|}
\hline & $\begin{array}{l}\text { Cases } \\
\text { detected }\end{array}$ & $\begin{array}{l}\text { Rate of case } \\
\text { detection }\end{array}$ & $\begin{array}{l}\text { Deformed } \\
\text { cases }(\%)\end{array}$ & $\begin{array}{c}\text { Smear + ve } \\
\text { cases }(\%)\end{array}$ \\
\hline \multicolumn{5}{|l|}{1 School survey } \\
\hline Ganapati et al. ${ }^{1}$ & 209 & $3 \cdot 0 / 1000$ & - & $3 \cdot 9$ \\
\hline Ganapati et al. ${ }^{2}$ & 1265 & $7 \cdot 0 / 1000$ & $3 \cdot 0$ & $2 \cdot 8$ \\
\hline Ganapati et al. ${ }^{3}$ & 733 & $10 \cdot 8 / 1000$ & - & $2 \cdot 4$ \\
\hline Ganapati et al. ${ }^{4}$ & 30 & $7 \cdot 3 / 1000$ & - & $3 \cdot 3$ \\
\hline A. L. Hospital ${ }^{5}$ & 2579 & $5 \cdot 1 / 1000$ & $1 \cdot 9$ & 1.9 \\
\hline \multicolumn{5}{|l|}{2 Survey of non- } \\
\hline children $^{4}$ & 30 & $8 \cdot 5 / 1000$ & - & $3 \cdot 3$ \\
\hline \multicolumn{5}{|l|}{3 Survey of children } \\
\hline of preschool age ${ }^{7}$ & 20 & $4 \cdot 7 / 1000$ & - & - \\
\hline \multicolumn{5}{|l|}{4 Contact survey } \\
\hline Ganapati et al. ${ }^{4}$ & 12 & $62 \cdot 0 / 1000$ & - & $8 \cdot 3$ \\
\hline Ganapati et al. ${ }^{6}$ & 41 & $44 \cdot 0 / 1000$ & - & $5 \cdot 0$ \\
\hline A. L. Hospital ${ }^{5}$ & 4444 & $31 \cdot 0 / 1000$ & 1.9 & $1 \cdot 5$ \\
\hline \multicolumn{5}{|l|}{5 Slum survey } \\
\hline Ganapati et al. ${ }^{4}$ & 176 & $10 \cdot 7 / 1000$ & - & $9 \cdot 9$ \\
\hline A. L. Hospital ${ }^{5}$ & 3808 & $9 \cdot 0 / 1000$ & - & - \\
\hline Revankar et al. ${ }^{8}$ & 381 & $11 \cdot 9 / 1000$ & - & $9 \cdot 2$ \\
\hline \multicolumn{5}{|l|}{$\begin{array}{l}6 \text { Survey of industrial } \\
\text { workers }\end{array}$} \\
\hline Koticha et al. ${ }^{9}$ & 316 & $17 \cdot 0 / 1000$ & $16 \cdot 0$ & $6 \cdot 3$ \\
\hline \multicolumn{5}{|l|}{$\begin{array}{l}7 \text { House-to-house } \\
\text { survey (not }\end{array}$} \\
\hline published) & 622 & $4 \cdot 8 / 1000$ & - & $4 \cdot 0$ \\
\hline
\end{tabular}


In view of the above, surveys of industrial workers should have been launched extensively. But this has not happened due to multifaceted difficulties. Surveys of industrial workers could hardly cover a satisfactory number of workers as they work in 3 shifts. Since the surveys disturb normal working in industry, the cooperation of management is limited. The most important difficulty experienced was that the cases detected often faced problems of social and vocational dehabilitation, making it necessary to have an undertaking of job security from the employer before undertaking industrial surveys.

Results of industrial surveys show a high case detection rate of 17 per 1000 with $16 \%$ deformed cases. ${ }^{9}$ Smear + ve cases, however, were only $6 \cdot 3 \%$, much less than what was expected.

House-to-house survey. To bring the entire population of Bombay under a leprosy control programme house-to-house surveys have recently been started. Though the results are not yet published, the population so far covered by the Acworth Leprosy Hospital reveals cases (predominantly with single skin patch) at the rate of 4.8 per 1000 with $4 \%$ infectious cases (Table 1 ). These figures are likely to be different in different parts of Bombay. This type of survey requires good public co-operation, otherwise it is difficult to cover a good number of people in spite of repeated visits and absentee surveys.

\section{Case detection through non-survey techniques}

An attempt made by Ganapati et al., using health education as the method of case detection, yielded interesting results (Table 2). Considering the difficulties in assessing the impact of health education, this particular attempt calls for reviewing in detail. Health education programmes in the form of film shows, talks with slide shows, group talks exhibiting photographs and exhibitions were carried out over a period of 3 years in a slum population of 20,000 in Bombay. In the fourth year, a total population survey was conducted. Of the 347 cases prevailing in the slum, $184(53 \%)$ had already come voluntarily during the first 3 years, which included $82 \%$ of the existing infectious cases, i.e. 27 out of $33 . .^{10}$ This achievement was attributed to the effect of health education and establishes a definite role of health education in case detection.

Table 2. Leprosy case detection by non-survey technique, i.e. by health education

\begin{tabular}{lccr}
\hline & $\begin{array}{c}\text { Non-survey } \\
\text { technique }\end{array}$ & $\begin{array}{c}\text { Survey } \\
\text { technique }\end{array}$ & Total \\
\hline Smear -ve & 157 & 157 & 314 \\
Smear +ve & 27 & 6 & 33 \\
Total & $184(53 \%)$ & $163(47 \%)$ & 347 \\
\hline
\end{tabular}

Ganapati et al. ${ }^{10}$

Other non-survey techniques like mass smear examination and immunological tests, e.g. lepromin and FLA-ABS or ELISA tests, tried elsewhere in India and in the world (see discussion) have so far not been used in Bombay for case detection.

\section{Work input against the achievements in active surveys}

Generally, in the present methods of survey, the targets of examination given per worker per day are 200 children for school surveys and 15 families (consisting of 60-75 members) for house-to-house and slum surveys. Based on the previous studies, the prevalence of leprosy among school children and the non-slum population is 5 per 1000 and that for the slum population is $10-12$ per 1000 . The corresponding rates for smear + ve leprosy are $0 \cdot 2,0 \cdot 4$ and $1 \cdot 1$ per 1000 respectively, ${ }^{11}$ Table 3 
Table 3. Work input in terms of field workers' days work per detected case

\begin{tabular}{|c|c|c|}
\hline \multirow[b]{2}{*}{ Type of survey } & \multicolumn{2}{|c|}{ Field workers' working days } \\
\hline & $\begin{array}{l}\text { Per case of } \\
\text { leprosy }\end{array}$ & $\begin{array}{c}\text { Per inf ectious case } \\
\text { of leprosy }\end{array}$ \\
\hline School survey & 1 day & 25 days \\
\hline $\begin{array}{l}\text { House-to-house survey } \\
\text { (non-slum population) }\end{array}$ & 3 days & 35 days \\
\hline Slum survey & 1.5 days & 15 days \\
\hline
\end{tabular}

shows the calculated work input in terms of field workers' days work required to detect each case of leprosy by survey methods in different sections of the population. Considering the fact that each worker has to put in 1-3 days work for every case and 15-35 days work for every infectious case, the present methods of survey appear to be very unimpressive, cost-effectively.

\section{Discussion}

The results of active surveys undertaken in Bombay during the last 15 years have shown that such surveys predominantly detect non-infectious cases with 1-2 skin lesions. However, these cases possess great potential for shelf-healing. Browne ${ }^{12}$ reported self-regression in $97 \cdot 2 \%$ of his cases with 1-2 skin lesions in the hyperendemic area. ${ }^{12}$ The author of the present paper also has observed complete cure in the absence of treatment in $98 \%$ of the 108 single lesion cases detected in school surveys. Under such circumstances, detecting these cases through active surveys, using tremendous man-power and expenditure, is of very little value.

Currently, while conducting surveys, there is an emphasis on complete stripping of the body which often poses great difficulties in the case of female examination in field conditions. From the reports, it is clear that $40 \%$ of the lesions are found on the exposed parts of the body and $20 \%$ are seen on the deltoid regions, arms, elbows and knees, ${ }^{2,5}$ the parts which can be exposed without difficulties. If the workers, therefore, are asked to restrict their examination to exposed and easily accessible parts of the body, there would be good co-operation from the adult population, the survey would be quick and about $60 \%$ of cases would still be detected. This will definitely relieve workers from unnecessary tension and they can pay more attention to signs like erythema and shiny skin which indicate early infectious leprosy.

In the interest of public health, identification and treatment of infectious cases of leprosy, is important. Since the present surveys are unable to detect such cases, there is an urgent need to develop a method by which their identification, preferably at the preclinical stage, is possible. Infectious patients, generally pass a substantial preclinical period of bacterial positivity (nasal and dermal) during which time they can be diagnosed only by smear examination. ${ }^{13}$ Asymptomatic bacterial positivity in contacts of leprosy patients, as well as in the people residing in hyperendemic areas, and their increased susceptibility to develop leprosy subsequently have been already reported. ${ }^{14,15,16}$ Though mass smear examination is likely to be unaccepted and operationally difficult, it can be applied extensively while examining the male adult population where prevalence of smear + ve leprosy is high. Supported by health education, this method would be of greater value from the public health point of view.

Routine palpation of peripheral nerves is known to be essential in making ultimate diagnosis of leprosy. Thickened nerves without overt symptoms and signs of neurological deficit would indicate 
early lepromatous leprosy (which, however, should be further proved by smear examination). Field workers are expected to palpate the nerves while examining for leprosy, but in the papers reviewed, nowhere has any specific mention been made about its exclusive importance, if any, in case detection.

Immuno-epidemiological tests, such as the lepromin test, FLA-ABS and ELISA tests, are also suggested to be of help in the identification of incipient multi-bacillary cases. ${ }^{17,18}$ Their potential in indicating infection with Mycobacterium leprae without acquisition of CMI is being tested at several places but their use will depend largely upon their application for masses in field conditions.

A comparative study, using health education against active surveys for case detection was in favour of health education. ${ }^{10} \mathrm{~A}$ similar study carried out at Dichpalli, India, not only proved the effectiveness of health education in case finding but also in case holding. ${ }^{19}$ However, it is difficult to assess the impact of wide-spread health education in the form of newspaper advertisements, documentaries in cinemas, posters and stickerscarrying messages in public vehicles, etc. in a city like Bombay.

In view of the above discussion to make case detection efforts more eff ective and meaningful, the following suggestions are made:

1 Health education should be more regularly used for case detection.

2 While conducting surveys, there should be emphasis on smear examination. Quick examination of exposed and easily accessible parts of the body should replace present methods of complete stripping. The importance of this approach should be included in the training of field workers.

3 Studies using immunological tests for detection of the infected susceptible population should be encouraged.

\section{Acknowledgment}

The author is gratef ul to the Superintendent at Acworth Leprosy Hospital for his valuable guidance and for giving permission to publish this paper.

\section{References}

${ }^{1}$ Ganapati R, Naik SS, Sane AB, Parikh AC. Leprosy among school children in Greater Bombay; Results of surveys. Lepr India, 1973; 45: 151-62.

2 Ganapati R, Naik SS, Pandya SS. Leprosy among school children in Greater Bombay_Clinical features. Lepr Rev, 1976; 47: 137-40.

${ }^{3}$ Ganapati R, Naik SS, Acharekar MY, Pade SS. Leprosy endemicity in Bombay-An assessment through surveys of municipal schools. Lepr Rev, 1976; 47: 127-31.

${ }^{4}$ Ganapati R, Pandya SS, Naik SS, Dongre VV, DeSouza NGA. Assessment of school surveys a s a method of case detection in an urban area endemic for leprosy. Indian J Med Res, 1977; 66: 732-6.

5 Acworth Leprosy Hospital, Consolidated Report of Anti-leprosy Activities-Leprosy Control in BombayEpidemiological Features against Demographic Background, 1890-1982.

${ }^{6}$ Ganapati R, Revankar CR, Christina, Romano. Associated cases in the families of school children with leprosy. Lepr Rev, 1978; 49: 43-6.

7 Revankar CR, Dewarkar PR, Mulchand Singh, Ganapati R. Leprosy in pre-school age. Lepr Rev, 1979; 50: 293-6.

${ }^{8}$ Revankar CR, Dudhalkar B, Girija D, Ganapati R. Leprosy survey in urban slums-Possibilities of epidemiological investigations. Lepr Rev, 1982; 53: 99-104.

9 Koticha KK, Pade SS, Nair PR R, Patre BB. Leprosy among Industrial workers in Bombay, India; Studies in retrospect and prospect. Int J Lepr, 1984; 52: 488-95.

10 Ganapati R, Revankar CR, Bandkar KR, Dongre VV. Leprosy detection through non-survey techniques. Indian J Lepr, 1984; 56: 622-5.

11 Ganapati R, Revankar CR, Dongre VV. Prevalence of leprosy in slums in Bombay including leprosy colony. Indian J Lepr, 1985; 57: 383-8. 
12 Browne SG. Self healing leprosy: Report on 2749 patients. Lepr Rev, 1974; 45: 104-11.

13 Guinto RS. Epidemiology of leprosy; Current concepts and problems. In A Window on Leprosy. Chatterjee BR (ed.), Calcutta: Gahdhi Memorial Leprosy Foundation, 1978; pp 36-53.

14 Figueredo N, Desai SD. Positive bacillary findings in the skin of contacts of leprosy patients. Int J Lepr, 1950; 18: $59-66$.

15 Taylor CE, Elliston EP, Gideon H. Asymptomatic infection in Leprosy. Int J Lepr; 1965; 33: 716-27.

16 Chatterjee BR, Taylor CE, Jacob Thomas, Naidu GN. Acid fact bacillary positivity in asymptomatic individuals in leprosy endemic area around Jhalda in W. Bengal. Lepr India, 1976; 48: 119-31.

17 Abe M, Ozawa T, Minagawa F, Yoshina Y. Immuno-epidemiological studies on sub-clinical inf ection with M. leprae. II. FLA-ABS and lepromin tests in school children in Miyako Island. In: Abstracts of sixteenth joint leprosy research conference-1981. Int J Lepr, 1981; 49: 503.

18 Douglas JT, Murry CJ, Lee JW, Worth RM. Comparison of ELISA antigens for early detection of preclinical leprosy. In: Abstracts of the XII International Leprosy Congress, New Delhi, 20-25 February 1984. Indian J Le pr, 1984; 56 (suppl No. 1), Abstract IX/370(A).

19 Hogerzeil LM, Reddy PK. General health education as the main approach to leprosy control, Dichpalli, India. Lepr Rev, 1982; 53: 195. 